F. Reprod. Fert. (1969) 18, 355-357

\title{
NOTES ON PARTURITION IN THE SHEEP
}

\author{
J. G. HINDSON AND BRENDA M. SCHOFIELD \\ Risdon's Fishleigh, Hatherleigh, Devon, and Department of Physiology, \\ Royal Veterinary College, London, N.W.1 \\ (Received 21st August 1968, accepted 25th October 1968)
}

A series of experiments has recently been carried out in ewes at the end of pregnancy in which parturition was monitored by the recording of intra-uterine pressure changes (Hindson, Schofield, Turner \& Wolff, 1965; Hindson, Schofield \& Turner, 1967, 1968). Some further observations have since been made which are relevant to the conclusions drawn; this paper is by way of being a postscript to the previous publications and carries the additional information.

The frequency of the intra-uterine pressure waves associated with parturition in this series was expressed as time per six waves. Since frequency can also be

TABLE 1

SHOWING THE NUMBER OF PRESSURE WAVES IN EAGH HALF-HOUR PERIOD BEFORE THE DELIVERY OF THE FIRST LAMB IN NINE EWES

\begin{tabular}{|c|c|c|c|c|c|c|c|c|c|}
\hline \multirow{2}{*}{$\begin{array}{l}\frac{1}{2} \text {-hour } \\
\text { before } \\
\text { delivery }\end{array}$} & \multicolumn{9}{|c|}{ Ewe } \\
\hline & 89 & 96 & 99 & 100 & 32 & 50 & 57 & 53 & 56 \\
\hline $\begin{array}{l}1 \\
2 \\
3 \\
4 \\
5 \\
6 \\
7 \\
8 \\
9\end{array}$ & $\begin{array}{l}20 \\
20 \\
21 \\
23\end{array}$ & $\begin{array}{l}19 \\
16 \\
17 \\
18 \\
15\end{array}$ & $\begin{array}{l}23 \\
20 \\
21 \\
20 \\
17 \\
16 \\
18\end{array}$ & $\begin{array}{l}24 \\
20 \\
20 \\
28 \\
21 \\
19 \\
21\end{array}$ & $\begin{array}{l}22 \\
20\end{array}$ & $\begin{array}{l}19 \\
18 \\
15 \\
18 \\
17 \\
17\end{array}$ & $\begin{array}{l}18 \\
19\end{array}$ & $\begin{array}{l}14 \\
16 \\
19 \\
15 \\
15 \\
14 \\
17 \\
15\end{array}$ & $\begin{array}{l}15 \\
17 \\
15\end{array}$ \\
\hline
\end{tabular}

expressed in waves per unit time, it seemed appropriate to make a second analysis in order to substantiate the conclusion drawn. Therefore, the original tracings were analysed in terms of waves per half-hour and Table 1 shows the counts in nine control ewes. From this it appears that the original conclusion still stands, namely that there is no change in frequency of the pressure waves during the last few hours of labour.

Pressure recording devices were implanted in both horns of the uterus in twin pregnancies where each horn carried one lamb (Hindson et al., 1968). It was found that one horn became dominant and developed pressure waves of about twice the amplitude of those in the other horn. The lamb in the dominant horn was the first to be presented at the cervix. At the time, no measurements 
were made of foetal size. In subsequent experiments, twin lambs have been weighed and measured immediately after birth and it was found that there was no consistent difference in the respective sizes of the first and second lambs to be delivered. Thus it is not possible to account for the sequential delivery of the lambs in terms of foetal volume.

To obtain some information regarding the disposition of the membranes in the twin pregnancies, seven ewes carrying one lamb in each horn were dissected at an appropriate stage of pregnancy in the slaughterhouse. It was found that in every case only the membranes associated with one lamb were applied to the internal surface of the cervix and this lamb occupied the greater

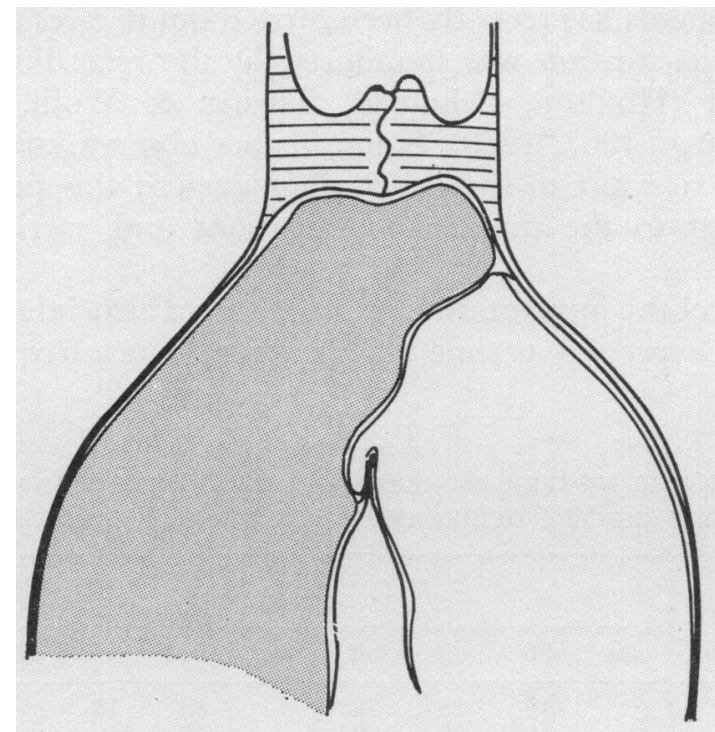

TExT-FIG. 1. Illustrating the respective areas of the uterus occupied by the membranes and cotyledons of twins in the pregnant ewe.

part of the body of the uterus as well as one horn. Presumably this lamb would have been delivered first. The second lamb was confined to the other horn. There were no obvious physical characteristics which might lead to a differential in the amplitude of the pressure waves developed by the two horns. In a few cases the membranes of the foetus confined to one horn invaginated a few inches into the other horn, as shown in Text-fig. 1.

Steven (1968) also demonstrated such a disposition of the membranes in a limited series of twin pregnancies. In his elegant experiments, he was investigating foetal blood supply to the placenta in the ewe and he found that there was no vascular continuity between the two foetuses. These findings are consistent with the suggestion (Hindson et al., 1968) that the differential between the two horns in the amplitude of the pressure waves may be associated with the local influence of the respective placentae and that the progesterone block may decline more rapidly in the dominant horn than in the secondary horn. How this might be brought about is obscure at the moment. 
Our thanks are due to Professor E. G. Amoroso for helpful comments on the manuscript.

\section{REFERENCES}

Hindson, J. C., Schofizld, B. M. \& Turner, C. B. (1967) The effect of a single dose of stilboestrol on cervical dilatation in pregnant sheep. Res. vet. Sci. 8, 353.

Hindson, J. C., Schofield, B. M. \& Turner, G. B. (1968) Parturient pressures in the ovine uterus. J. Physiol., Lond. 195, 19.

Hindson, J. C., Schopield, B. M., Turner, G. B. \& Wolff, H. S. (1965) Parturition in the sheep. 7. Physiol., Lond. 181, 560.

Steven, D. H. (1968) Placental vessels of the foetal lamb. F. Anat. 103, 539. 